\title{
Habitat abundances of a cricket-parasitizing wasp Rhopalosoma nearcticum (Hymenoptera: Rhopalosomatidae) in a United States mid-Atlantic park
}

\section{Edward M. Barrows}

Laboratory of Entomology and Biodiversity and Georgetown University Center for the Environment, Department of Biology, Georgetown University, Washington DC, USA; barrowse@georgetown.edu

Received 25 August 2013; revised 28 September 2013; accepted 14 October 2013

Copyright (C) 2013 Edward M. Barrows. This is an open access article distributed under the Creative Commons Attribution License, which permits unrestricted use, distribution, and reproduction in any medium, provided the original work is properly cited.

\begin{abstract}
Adults of the nocturnal, cricket-parasitizing wasp Rhopalosoma nearcticum flew in Dyke Marsh Wildlife Preserve (DMWP) from late June through late September, based on a 2-year, Malaise-trap sample of 617 individuals from three habitats. These wasps were significantly more abundant in the floodplain forest compared to the tidal, freshwater marsh and forest-marsh ecotone. Females were more likely to be in the ecotone and marsh than males. The pooled sample from all three habitats was significantly male biased. This study provides baseline information on $R$. nearcticum that can be used in assessing the health of the DMWP entomofauna in view of global change, accelerating DMWP erosion and marsh loss, invasive species, and other threats to this fragile preserve.
\end{abstract}

Keywords: Deciduous Forest; Freshwater Tidal Marsh; Malaise-Trap Sampling; Parasitic Wasp; Phenology; Sex Ratio

\section{INTRODUCTION}

The nocturnal, parasitic wasp Rhopalosoma nearcticum Brues is native to Maryland south through Florida and west through Texas, and Malaise-trap samples indicate that this wasp can be common in some parts of its range such as Florida [1,2]. This wasp is a larval parasite of Hapithus and Orotharis crickets [3-5]. Fifth-instar R. nearcticum larvae leave their hosts, spin cocoons and pupate in soil, and emerge as adults from their cocoons in summer.
This report regards the flight periods, abundances, and sex ratios of adult $R$. nearcticum in the floodplain forest, tidal freshwater marsh, and their ecotone based on Malaise-trap samples from Dyke Marsh Wildlife Preserve (DMWP) part of the George Washington Memorial Parkway (GWMP), a park in the US Mid-Atlantic Region administered by the National Park Service. This study, which is part of the DMWP Arthropod Survey, is the first quantitative investigation of $R$. nearcticum abundances in different habitats, including a rare freshwater marsh.

\section{MATERIALS AND METHODS}

Using six Townes-style Malaise traps [6], my lab collected arthropod samples from April 1998 through December 1999 in Dyke Marsh Wildlife Preserve, described by Johnston [7]. The Preserve includes 154 ha of land on the west side of the Potomac River and part of the River in Fairfax County, is $0-3.25 \mathrm{~m}$ above sea level (B. Helwig, pers. comm.), and contains the largest remaining freshwater tidal marsh in the Washington, DC, Area. This fragile park has experienced marked degradation in recent decades due to air pollution, alien invasive organisms, accelerating erosion and marsh loss, and water pollution $[7,8$, pers. obs.].

Two traps were run in each of three habitats-low forest, freshwater tidal marsh, and the ecotone between them as described by Barrows et al. [9]. The six traps were in a broad transect that ran in an east-west direction. The ecotone (defined as $10 \mathrm{~m}$ on each side of the forestmarsh edge) ran about $200 \mathrm{~m}$ in north-northeast and south-southwest direction in the sampling area. I oriented each trap so that its longitudinal axis ran east-west, and its collecting head faced due east. The forest traps were about $50 \mathrm{~m}$ west of the ecotone, and the marsh traps av- 
eraged about $60 \mathrm{~m}$ east of the ecotone. The mid-point location of the forest traps is $38.77194^{\circ} \mathrm{N}, 77.05083^{\circ} \mathrm{W}$; ecotone traps, $38.77139^{\circ} \mathrm{N}, 77.05056^{\circ} \mathrm{W}$; and marsh traps, $38.77172^{\circ} \mathrm{N}, 77.04990^{\circ} \mathrm{W}$.

Barrows et al. [9] described the Malaise traps in detail. In summary, each trap was $1.2 \mathrm{~m}$ wide, $1.7 \mathrm{~m}$ long, $1.0 \mathrm{~m}$ high at its back and $2.0 \mathrm{~m}$ high at its front and mounted on a floating platform that could rise and fall with the tide which can be as high as about $1 \mathrm{~m}$ during nonflood periods. The wasps flew or crawled into a trap's collecting head where they were preserved in $95 \%$ ethanol. Forest and ecotone traps ran during the entire 21-mo sampling period. My lab removed marsh traps from late December 1998 through late March 1999, because possible flooding during that time could have destroyed them. The lab emptied traps every $3-24$ days, collecting samples less frequently during November through March when daily arthropod captures were low.

To identify $R$. nearcticum, I used the insect collection at the National Museum of Natural History, Washington, D. C., and the key in Stange [2]. To test for possible differences in wasp numbers among habitats, I used repeated-measures analysis of variance (rmANOVA) and the Scheffé test [10] on data transformed into cube-root values to meet the assumption of homoscedasticity. To test whether sample sex ratios were different than hypothetical 50:50 sex ratios, I used an online Fisher's Exact Probability Test program [11]. Voucher specimens are in the Georgetown University Arthropod Collection.

\section{RESULTS AND DISCUSSION}

The traps captured 617 adult $R$. nearcticum during the 2 -yr trapping period. This was the only rhopalosomatid species found in the samples. More R. nearcticum occurred in 1998 samples than in the 1999 samples (Table 1), possibly as a result of this species' natural population-size fluctuations. Adults flew from late June through late September and had a longer flight season in 1998 compared to 1999 (Table 1). Peak abundances were in early August 1998 and mid-August 1999. Farther south in Florida, US, R. nearcticum flew from May through October [2].

In 1999 and in both years combined, $R$. nearcticum was significantly more common in the forest than in the other two habitats (Table 1). This may be due to a greater abundance of hosts, other resources, or both in the forest than in the other habitats, subjects not investigated in this survey. Overall in DMWP, arthropod abundances among the three habitats vary among taxa. For example, two lampyrid species and a group of five mecopteran species were also more common in the forest than the other habitats $[12,13]$. In contrast, a sialid species was more common in the ecotone [9].

Sample sex ratios of $R$. nearcticum were male biased in 1999 and both years combined (Table 1). If this species has an actual adult sex ratio of 1:1, male-biased trap samples do not indicate this species' true adult sex ratio. Both females and males were common in the forest, but females were more likely to be in the ecotone and marsh than males. Females may have been searching outside of the forest for prey and possibly other resources, and males may have been searching primarily in the forest for females. Sample sex ratios from other DMWP samples varied with taxon. For example, one sialid species and one lampyrid species and genus had statistically male-biased sex ratios, but one panorpid species had a female-biased sex ratio $[9,12,13]$. Many aspects of $R$. nearcticum's biology await study including foraging and mating behavior and population-size responses to environmental factors.

In conclusion, this investigation found that adult $R$. nearcticum occurred in summer and early autumn, primarily in the flood-plain forest, providing baseline data that can inform future monitoring and managing arthropods in DMWP. Since this is a time of rapid global change, it is worthwhile to resample DMWP for $R$. nearcticum and other arthropods on a regular basis. The preserve is near sea level and threatened by higher tides due to sea-level rise that could eliminate much of DMWP in this century.

Table 1. Abundance in three habitats, \% females, and flight periods of Rhopalosoma nearcticum based on Malaise-trap samples from Dyke Marsh Wildlife Preserve, Virginia.

\begin{tabular}{|c|c|c|c|c|c|c|c|c|c|}
\hline \multirow{2}{*}{ Year } & \multicolumn{4}{|c|}{ Number of wasps ${ }^{1}$} & \multicolumn{4}{|c|}{$\%$ female (sample size) } & \multirow{2}{*}{ Flight Period } \\
\hline & Forest & Ecotone & Marsh & Total & Forest & Ecotone & Marsh & Total & \\
\hline 1998 & $\begin{array}{c}117.5 \pm 70.0 \\
(68-167,235) \mathrm{a}\end{array}$ & $\begin{array}{c}11.5 \pm 9.2 \\
(5-18,23) \mathrm{a}\end{array}$ & $\begin{array}{c}9.5 \pm 3.5 \\
(7-12,19) \mathrm{a}\end{array}$ & 277 & $39^{*}(235)$ & $91^{* *}(23)$ & $100^{* * *}(19)$ & 47 (277) & $\begin{array}{c}24 \text { June - } 28 \\
\text { August }\end{array}$ \\
\hline 1999 & $\begin{array}{c}164 \pm 46.7 \\
(131-197,328) a\end{array}$ & $\begin{array}{c}3.0 \pm 2.8 \\
(1-5,6) b\end{array}$ & $\begin{array}{c}3.0 \pm 1.4 \\
(2-4,6) b\end{array}$ & 340 & $30^{* * *}(328)$ & $83^{2}(6)$ & $100^{2}(6)$ & $32^{* * *}(340)$ & $\begin{array}{l}2 \text { July - } 26 \\
\text { September }\end{array}$ \\
\hline 1998-1999 & $\begin{array}{c}281.5 \pm 116.7 \\
(199-364,563) \mathrm{a}\end{array}$ & $\begin{array}{c}14.5 \pm 6.4 \\
(10-19,29) b\end{array}$ & $\begin{array}{c}12.5 \pm 2.1 \\
(11-14,25) b\end{array}$ & 617 & $33^{* * *}(563)$ & $90^{* * *}(29)$ & $100^{* * *}(25)$ & $30^{* * *}(617)$ & $\begin{array}{c}24 \text { June - } 26 \\
\text { September }\end{array}$ \\
\hline
\end{tabular}

${ }^{1}$ Within year, trap site totals $(\mathrm{N}=2$ traps) followed by different letters indicate that their respective sites have significantly different abundances from one other $\left(P \leq 0.05\right.$, ANOVA, Scheffé Test, using cube-root transformed data) $;{ }^{2}$ This sample is too small for analysis with Fisher's Exact Probability Test; ${ }^{*} P \leq 0.05 ;{ }^{* *} P \leq$ $0.01 ;{ }^{* * *} P \leq 0.001$ (Fisher's Exact Probability Test). 


\section{ACKNOWLEDGMENTS}

Many people have helped with the Dyke Marsh Wildlife Preserve Arthropod Study (DMWPAS), including R. O'Hanlon (building and maintaining traps), K. Differding, L. Gardner de Beville, H. Goldfrank, D. L, Mead, and S.-M. K. Wise (processing specimens). Aaron F. Howard and H. A. Bookstein critically read a preliminary draft of the manuscript of this paper. Friends of Dyke Marsh, the National Park Service, and the Washington Biologists' Field Club provided financial support for the DMWPAS.

\section{REFERENCES}

[1] Krombein, K.V., Hurd, Jr., P.D., Smith, D.R. and Burks, B.D. (1979) Catalog of the Hymenoptera in America North of Mexico. Smithsonian Institution Press, Washington, DC, 1199-2209.

[2] Stange, L.A. (1991) Rhopalosomatidae of Florida. Entomology Circular No. 341. Florida Department of Agriculture and Consumer Services Division of Plant Industry. http://www.doacs.state.fl.us/pi/enpp/ento/entcirc/ent341.p df

[3] Hood, J.D. (1913) Notes on the life history of Rhopalosoma poeyi Cresson. Proceedings of the Entomological Society of Washington, 155, 145-147.

[4] Brues, C.T. (1943) The American species of Rhopalosoma. Annals of the Entomological Society of America, 36, 310-318.

[5] Gurney, A.B. (1953) Notes on the biology and immature stages of a cricket parasite of the genus Rhopalosoma. Proceedings of the United States National Museum, 103, 19-34.

http://dx.doi.org/10.5479/si.00963801.103-3313.19
[6] Townes, H. (1972) A light-weight Malaise trap. Entomological News, 83, 239-247.

[7] Johnston, D.W. (2000) The Dyke Marsh Preserve ecosystem. Virginia Journal of Science, 51, 223-272.

[8] Litwin, R.J., Smoot, J.P., Pavich, M.J., Markewich, H.W., Oberg, E., Helwig, B., Steury, B., Santucci, V.L., Durika, N.J., Rybicki, N.B., Engelhardt, K.M., Sanders, G., Verado, S., Elmore, A.J. and Gilmer, J. (2011) Analysis of the deconstruction of Dyke Marsh, George Washington Memorial Parkway, Virginia-Progression, geologic and manmade causes, and effective restoration scenarios. US Geological Survey Open-File Report 2010-1269, 80 pp. http://pubs.usgs.gov/of/2010/1269/pdf/ofr20101269.pdf

[9] Barrows, E.M., McIntyre, A.M. and Flint, Jr., O.S. (2005) Alderfly (Neuroptera: Sialidae) flight periods, sex ratios, and habitat use in a Virginia freshwater tidal marsh, low forest, and their ecotones. Proceedings of the Washington Entomological Society, 107, 693-699.

[10] SPSS, Inc. (2009) SPSS Advanced Model 17.0. SPSS, Inc., Chicago.

[11] Langsrud, Ø. (2012) Fisher's Exact Test. http://www.langsrud.com/fisher.htm

[12] Barrows, E.M., Arsenault, S.B. and Grenier, N.P. (2008) Firefly (Coleoptera: Lampyridae) flight periods, sex ratios, and habitat frequencies in a United States Mid-Atlantic freshwater tidal marsh, low forest, and their ecotone. Banisteria, 31, 47-52.

[13] Barrows, E.M. and Flint Jr., O.S., (2009) Mecopteran (Mecoptera: Bittacidae, Meropeidae, Panorpidae) flight periods, sex ratios, and habitat frequencies in a United States Mid-Atlantic freshwater tidal marsh, low forest, and their ecotone. Journal of the Kansas Entomological Society, 82, 223-230. http://dx.doi.org/10.2317/JKES0807.15.1 